\title{
4. Testing times: Kiwi journalists and the military
}

\section{ABBSIRACI}

War correspondents, long the object of popular fascination, have been the focus of academic study since Phillip Knightley published The First Casualty in 1976. While New Zealand journalists did not cover the second Iraq War in 2003, the furore over the US practice of 'embedding' journalists was felt in New Zealand. Drawing on in-depth interviews with seven seasoned defence reporters, this article examines the relationship between the New Zealand Army and journalists during times of conflict. Concentrating on wars in Bosnia and East Timor (Timor Leste), the interviews cover defence journalists' perceptions of constraints on reporting, spin in military communication and changing military attitudes to media relations. The comments underscore the tensions inherent in the media's reliance on military support. While it appears Kiwi journalists' experiences are generally more satisfactory than many of their overseas counterparts, the article considers some implications of military public relations in the face of New Zealand's under-resourced media industry.

Keywords: Bosnia; East Timor; embedding; war correspondents

\section{DENISE MACKAY and MARGIE COMRIE \\ Red Cross \\ Massey University}

\section{Introduction}

T TAR journalism fulfils many of the news values that drive our media industries. The inherent conflict, tension and drama of war coverage makes it commercially rewarding (Boyd-Barrett, 2004; Webster, 2003), and media coverage of military conflicts increased towards the end of the 20th century encouraged by globalisation and enabled by technological advances (Rafeeq, 2007)

The alliance between the military and journalists is, however, recognised as uneasy (Braestrup, 1985; Hooper, 1982; Kennedy, 1993; Mirchandani; 2003; 
Young, 1992). Such tensions run deeper than the normal friction reported between public relations practitioners and journalists (Grunig, 1990; Marken, 2001). As well as differing agendas, Braestrup (1985) suggests the problems stem from profound cultural differences. The military culture, with its accent on conformity, control, discipline, accountability, group loyalty and cohesion, finds itself in wartime up against a group that is individualistic, competitive, work conscious, impatient, lacking internal rules and standards, varied in its needs, suspicious of authority and hard pressed by deadlines and the need to obtain good film or definitive information at short notice.

Military and non-military commentators agree the media are the best means for the military to communicate with the public (Bridges, 1995; Galloucis, 1996; Sambrook, 2003). Particularly during wartime, journalists are dependent on the goodwill of various military forces for source material, physical access and safety. The military and supporting governments have become increasingly efficient in exploiting this power as they recognise the importance of media in winning over public opinion and legitimising military action. Hiebert (1993) describes public relations as a 'primary weapon of war' (p. 30), while Harrison (2004) argues that news management in times of conflict has become imperative, resulting in the creation of large military public affairs units.

The military-media connection is frequently traced back to the Crimean War in the 1850s, when William Russell's dispatches to The Times were 'the beginning of an organised effort to report a war to the civilian population at home using the services of a civilian reporter' (Knightley, 2000, p. 2). However, many recognise Vietnam as the watershed in the relationship (see for instance Braestrup; 1985, Kennedy, 1993, Gorman and McLean, 2003), with Knightley characterising the war as an 'aberration' (p. 482). Vietnam coverage was characterised by media freedom; journalists went where they wanted, when they wanted, and their copy was not scrutinised (Braestrup, 1985). Young and Jesser (1997) describe Vietnam as the first real 'televised' war and one where the military found itself attempting to control media less than fully supportive of their country's involvement. While there was initial public support, people began to find evidence provided by television at odds with what their government was telling them was happening. Williams (1993) argues that the Tet offensive, occurring 'in front of the reporters' own eyes' (p. 311) was the turning point, beyond which the US media became more 
critical of the war, giving greater coverage and concentrating more on civilian suffering and atrocities.

Gorman and McLean (2003) say the 'Vietnam experience' had a significant affect on governmental and military policy in dealing with the media. It quickly became clear the media had the ability to divide home front opinion and erode and undermine the war effort (Braestrup, 1985). The British invasion of the Falklands in 1982 and the US invasion of Grenada in late 1983 indicated that both governments and their militaries were not prepared to allow the media to influence their activities. According to Braestrup, both conflicts were characterised by limited access for journalists, censorship, poor communication facilities, along with some deception and even disinformation. In 1990, as the first Gulf War approached, both parties remained deeply distrustful of each other (Gallouicis, 1996). The US military set up a media pool system that effectively allowed only reporters who had 'signed up' access to logistics and troops. Gallouicis reports that pools stayed together, negating the ability to get a scoop, and they were 'minded' by military public affairs officers who the media complained guided them to 'good news stories' only.

Hickey (2002), basing his arguments on more than 100 interviews with editors, correspondents, bureau chiefs, top news executives and media critics, says journalists have been denied access to American troops in the field in Afghanistan during the so-called War on Terror, to a greater degree than any other previous war involving US military forces. The unstated reason, Hickey argues, is the Pentagon's determination to control the flow of news from the front in case images and descriptions of civilian bomb casualties might erode public support.

The second Iraq War-Operation Iraqi Freedom ${ }^{1}$ - introduced the term 'embedded reporters' to the lexicon. The notion of a journalist integrated into a military unit and experiencing conflict in real time was first proposed by the French military as 'emersion' but was never used (Young, 1992). The concept grew from the Pentagon's media policy drafted in conjunction with senior Washington television and print media chiefs to allow what was perceived as a greater media freedom on the battle field (Hickey, 2002; Katovsky \& Carlson, 2003). Embedded reporters have been accepted with open arms by military leaders (Pasquarett, 2003; Russell, 2004), yet some reporters and media commentators remain deeply sceptical (Seccombe, 2003; Sambrook, 2003). The pros and cons of embedded reporting have been 
widely discussed (see for instance Jacobs, 2003; Katovsky \& Carlson 2003; Mirchandani, 2003; Pasquarett, 2003; Russell, 2004; Sambrook, 2003; Williams, 2004). Most commentators agree that the positive aspects of embedding include the ability to capture the human face, the professionalism and at times the disorientation and confusion of war, along with increasing the speed of information flowing from conflict areas to viewers. However, an often-reported downside of embedding is the perceived loss of reporters' freedom, not only because of rules they follow to remain embedded ${ }^{2}$, but also because of the bonding taking place between reporters and military personnel (Jensen, 2003). What is often missed in reports from embeds is accuracy or authority, according to Sambrook. He says you get a vivid snapshot—war through a keyhole; while the grass roots level of warfare is reported, bigger issues are ignored.

Embedding was discussed in the New Zealand media in $2004^{3}$. The New Zealand Defence Force's position, articulated by Defence Press Officer Commander Sandra McKie, is that the NZDF does not embed journalists-it facilitates them. 'Embedded means something completely different,' she says (in Dow, 2004, p. 24). Sandra McKie argues that safety is the main reason for facilitating visits, along with 'making sure our people, who had a job to do, could manage that and get on with the duties they had to do as well' (p. 24). However, Paul Buchanan from the University of Auckland (also cited in Dow), disagrees, saying if the military were to start defining its mission to include the safety of compatriot reporters, it would complicate its job immensely. Buchannan also criticises the quality of reporting on NZ troops: 'You get pictures of the troops doing the haka for the PM and talking about how much they want to help the people of Iraq. This is stuff ...ginned up in Wellington rather than the hard reality on the ground in Basra' (p. 24).

Jon Stephenson, the only New Zealand journalist based in Iraq while New Zealand troops were stationed there, also disagrees with Commander McKie. Stephenson says defence force policy was to allow only embedded journalists access to the Kiwi engineers in Iraq". 'My general impression was that the NZDF did their best to restrict and control journalists' access to the engineer contingent in Basra' (Dow, 2004, p. 24). Stephenson says he tried to interview the engineers and was told to leave the base, as he was not an accredited journalist with the NZDF. In the same article, academic and former journalist Jim Tully says he sees no difference between the terms 'facilitated' and 'embedded' as both indicate news management to a certain degree. 
One of the most widely recognised area of contention between the military and the media is the public's 'right to know' (Gorman \& McLean, 2003; Kennedy, 1993; Braestrup, 1985). Mercer, Mungham \& Williams (1987) argue that the essence of successful warfare is secrecy; the essence of successful journalism is publicity. From the military perspective, Mackie (1999) says, while in practice, control of the military resides with the government, it is the media that provide insight into the machination of the Armed Forces. Therefore, the media are an informal but necessary check and balance on the military and the public's right to know what is happening both in peacetime and in war. However, Hagar (cited in Taylor, 2004) feels the New Zealand government exerts too much control. From the late 1990s the New Zealand Defence Force has had more overseas deployments than at any time since Vietnam, yet, Hagar says, few stories have been produced by the media that have not been strictly controlled and organised by military PR staff. Overall, Hagar contends that the government sector with its growing PR staff numbers is getting more secretive.

Young (1992) feels the biggest problem in the relationship between the military and the media is getting the balance between the public's right to know and an open exchange of information versus the need for military secrecy and security. The two are essentially irreconcilable, Hickey (2002) says, yet both the military and the media have a valid agenda. Military authors (Bridges, 1995; Float, 2000) argue that the need for operational security is stronger than the necessity for complete openness, while media argue that the term 'operationally sensitive' can be used as a cop out. Jansen (2003) says operational security is in practice defined as whatever field commanders want to censor. For instance, the Australian Defence Force operates a policy ${ }^{5}$ whereby accredited reporters must subject stories for checking before they are transmitted and Terry O'Connor, an Australian defence reporter says: 'I accept there is a real need for some check on reportage that may endanger lives but I believe the Australian system is still open for abuse by the military' (cited in Mirchandani, 2003, p. 64).

Media, unsurprisingly, view any means of controlling their right to report truthfully and unencumbered as undemocratic (Katovsky \& Carlson, 2003). However, New Zealand journalism teacher Tully points out that while journalistic independence is incompatible with the military agenda, journalists are in a cleft stick: 'Do journalists stand on their dignity and refuse to 
go as embedded or facilitated reporters, or do they take the pragmatic view that at least they are there and bear witness to events acknowledging the restrictions placed upon them?' Tully maintains he would go despite the restrictions: 'It is far from desirable, but in the best interests of the public' (Dow, 2004, p. 24).

\section{Method}

The relationship between the media and the military has been systematically studied overseas, particularly in Britain the United States, but not in New Zealand. The interviews with journalists reported on here were conducted as part of a wider investigation of media and the New Zealand Army relations during the deployments in Bosnia and East Timor designed to fill this research gap (Mackay, 2005).

A long serving Air Force officer, who had worked in Defence Public Relations during both conflict periods helped prepare a list of potential interviewees. Journalists who had covered both conflicts and had travelled to both locations were considered top priority. Getting a mixture of print, radio and television was also an important factor. After making initial contact, a print journalist on extended leave was dropped from the list and replaced by a former print journalist, who had worked as a defence reporter and visited East Timor. A total of seven made up the final group.

The project was cleared by the NZ Army and Massey University's Human Ethics Committee. The researcher prepared a questionnaire based on the academic literature and on her understanding and experience of military public relations. Interviews were designed to explore two core questions: How do the media and the military interact during periods of conflict? How can relationships be enhanced in the future?

The questionnaire was pre-tested (largely for length and clarity) using a print journalist employed by the NZ Defence Force. As a result the questionnaire was trimmed back to take about 45 minutes, and focused more closely on the key research aims. Interviewees were contacted, generally by phone. All agreed to take part, were sent information sheets and consent forms, and asked about their preference for interviews (face to face, telephone, mail or email). Interviews were conducted in July and August 2004. Three respondents were interviewed face to face, two by email, one by phone and one completed a questionnaire by conventional mail. 
THE FUTURE OF MAINSTREAM MEDIA

\section{Results}

Interviewees' characteristics and experience

The journalists were asked about their journalism experience, how long they had worked as defence reporters, what media they had worked in, where they worked currently, which conflict areas they had visited and whether they had been taken on other trips by the Army. As Table 1 indicates, the

Table 1: The Interviewees
\begin{tabular}{|l|c|c|c|c|c|c|c|}
\hline Journalist & A & B & C & D & E & F & G \\
\hline Years in journalism & 34 & 30 & 24 & 38 & 40 & 15 & 13 \\
\hline Defence reporting & 10 yrs & $\begin{array}{c}30 \text { yrs } \\
\text { sporadic }\end{array}$ & 6 yrs & 7 yrs & $\begin{array}{c}21 \text { yrs } \\
\text { sporadic }\end{array}$ & $5-6$ yrs & 6 yrs \\
\hline Background & Print & $\begin{array}{c}\text { No } \\
\text { reply }\end{array}$ & $\begin{array}{c}\text { Print } \\
\text { radio }\end{array}$ & $\begin{array}{c}\text { Print } \\
\text { PR }\end{array}$ & $\begin{array}{c}\text { Print } \\
\text { TV } \\
\text { radio }\end{array}$ & $\begin{array}{c}\text { No } \\
\text { reply }\end{array}$ & Print \\
\hline Current role & Print & TV & $\begin{array}{c}\text { Radio } \\
\text { Print }\end{array}$ & $\begin{array}{c}\text { TV } \\
\text { Radio }\end{array}$ & PR \\
\hline Gender & Male & Male & Male & Male & Male & Female & Female \\
\hline Area visited & $\begin{array}{c}\text { Bosnia } \\
\text { East } \\
\text { Timor }\end{array}$ & Neither & $\begin{array}{c}\text { East } \\
\text { Timor }\end{array}$ & $\begin{array}{c}\text { East } \\
\text { Timor }\end{array}$ & $\begin{array}{c}\text { East } \\
\text { Timor }\end{array}$ & Neither & $\begin{array}{c}\text { East } \\
\text { Timor }\end{array}$ \\
\hline NZDF trips & Yes & No & Yes & Yes & Yes & Yes & Yes \\
\hline
\end{tabular}

Note: *Journalists all covered other rounds as well as their defence responsibilities. While all the reporters accepted the title 'defence reporter' it might be also fair to term all who had covered areas of conflict 'war correspondents'.

seven respondents were highly experienced and had worked for many of the major media outlets in New Zealand. Years in journalism ranged from 13 to 40 with a combined total of 194 years of reporting. Interviewees were also seasoned defence reporters all with at least five years on the round and two with over 20 years 'on and off' reporting on defence matters. The majority of respondents had started in print journalism, two had worked in print, radio and television and two mentioned past or current work in public relations. 
Two interviewees had been to both conflict areas, three others had been to East Timor, with one noting, 'about seven times'. Two had not been to either location. Four of the seven had joined the New Zealand Defence Force (NZDF) on trips to other areas such as the Solomon Islands, Bougainville and Nuie.

\section{Experience of logistical support}

All those who had been to either Bosnia or East Timor had used NZDF transport. One respondent had also flown to East Timor on civilian aircraft. Respondents were asked how the NZDF helped them before their departure to Bosnia or East Timor. Three mentioned that the NZDF assisted them with their departure [at either Ohakea or Whenuapai] and helped with media accreditation for the area they were going to (United Nations media accreditation was required for both Bosnia and East Timor). Three long-established reporters mentioned briefings. However, their experiences varied. One described briefings as 'extensive and satisfactory', but two others, mentioned they would have liked briefings. One felt a joint NZDF and MFAT briefing would have been useful and the other said 'I recall one time when I potentially got into trouble. I was a UN accredited journalist. I was given a UN media pass, but had no idea what the obligations were that flowed from that.' Both journalists who covered but did not travel to either conflict zone said they had received all the information needed from defence force sources for their New Zealand-based reporting.

Those journalists who had been to conflict zones all agreed that media access to the Area of Operations (AO), mobility, logistical arrangements and their access to military information were key in successful coverage of conflict. They all recognised their dependence on the military for logistical support and the limitations this imposed, but felt they would never have had the chance to get the information they did without support. One commented: 'New Zealand media organisations are not prepared to fund the cost, so we go with the NZDF,' while a television journalist said, 'Getting pictures is essential, so access to the AO is essential.' Another journalist who had been unable to take up the offer said the trip to the conflict area was 'too short for radio use'.

\section{Media relations and 'spin'}

The defence journalists were asked to recall good or bad experiences with NZ Army PR staff, and the responses centred mostly around trust. One 
noted: 'There were some people that I didn't get on with, there were relationship issues, I didn't build a rapport with them and it made a difference to the trust we had.' A television reporter, who was not in Bosnia or East Timor but recently travelled with the NZDF to Iraq coloured his answers with examples of trust and rapport. For instance:

\begin{abstract}
We were in Iraq when [Army officer] was involved in a vehicle explosion. We didn't know it had occurred until our office called us to let us know they had picked up initial reports of the explosion. I asked one of the Army to confirm the situation. He said, 'Yes', but asked us to hold the information until the next of kin could be informed. I had deadlines to meet and needed to file. We were able to come to an agreement that allowed me to report and allowed the Army to protect the family. We solved the issue with face to face discussion and everyone was happy.
\end{abstract}

A radio journalist reported an experience that made him question the military and his colleagues. While visiting a village in East Timor with New Zealand media and a VIP group they were briefed by an Army officer who mentioned malnutrition in the area. The respondent felt the briefing raised significant questions:

I got fobbed off [by the NZDF] when I sought clarification. I finally went to the UN and they said they had investigated complaints of malnutrition but found no evidence. By that stage my colleagues has filed their stories but the facts were not true. I think both parties were in the wrong - the journos should check their facts and the Army should not shoot its mouth off.

On the whole, participants did not consider the Army put a lot of spin on information, with a typical response being, 'No more than any other politically sensitive organisation.' Another experienced journalist, now in television, said he had 'no worries about spin, it is my job to see through it.' Only one journalist, also in television, felt the Army puts 'a lot' of spin on information. He said it was to be expected and based evidence on the fact that NZDF tends to use designated spokespeople: 'Soldiers will rarely agree to interview because they have been instructed not to.' 
To place their perceptions of military spin in perspective, defence journalists were asked to comment on media manipulation by government departments in general. The majority-six-agreed there was media manipulation by government departments in New Zealand, with the general consensus that spending resources to place their organisations in a positive light, and attempting to restrict access when under fire was to be expected. One journalist pointed out: 'There is a huge amount of money spent in this area.' Another said: 'It is not the role of a government department to manipulate or mislead the public. They are protecting what against whom?' The journalist who commented there was 'not a lot' of media manipulation by government departments, added, 'But people don't ask questions. If you don't ask you don't get. There is a limit on how much information people will volunteer.'

Several called the Army just another government department when discussing manipulation, although two of the respondents said the Army was better to deal with than most of the public sector. One participant, with 38 years in journalism, said:

Our military depends on the politicians for its very existence. Politicians depend on people voting for them for theirs, and to a very large degree that depends on information and spin. It's a bugger isn't it?

Journalists were also asked how they thought the military perceived the media. They all said that on the whole, the military saw media in a negative light but recognised their importance. 'A necessary tool' was one response, while another interviewee said, 'A useful tool but a pain in the arse!' However, a journalist further commented: 'They are suspicious in the same way that everyone is suspicious of the media.'

All the respondents said that during times of conflict the army became more suspicious and more sensitive to the media and more focused on army tasks. One well-established print journalist who has covered defence issues for 10 years felt the military's attitudes to the media differed in Bosnia and in East Timor. 'In Bosnia there were rumours circulating that the media had been setting up scenes for television. I don't know if it was true, but the soldiers seemed to believe it and that made them suspicious of all media.' Interviews with Army PR staff, also indicated a change; three who had served in Bosnia spoke of strained relations with the media and one of these who had 
also served East Timor said senior commanders had begun to have a better appreciation of the importance of the media and that the army was employing more experienced PR staff (MacKay, 2004). Two print journalists believed that Army personnel's attitude to the media was shaped more by past experience than by their rank level or age. On the other hand, two others, who had been in Bosnia and East Timor respectively, felt that there was a difference in attitudes displayed by different ranks. One said, 'The top brass appear to embrace openness and some are even pretty savvy in managing the media.' The other's view was, 'junior ranks are good, senior ranks are good, it is the mid level who are the most twitchy as they think they have the most to lose.'

Another journalist pointed out that attitudes to the media stem 'from what might be termed the 'policy perception' of media, a matter very relevant at present and something I believe stems from a particularly sensitive Cabinet, rather than any sense of individual solders' perceptions of the media.'

\section{Limits on the 'right to know'}

Participants were asked if they thought there should be a limit on the public's 'right to know' when reporting on military operations. They all believed there were limits on what they should report if lives were to be put in danger. For instance: 'I could understand if the military chose not to give me information if it might jeopardise or endanger lives unnecessarily.' But most had qualifications. One journalist said a decision for him to hold back on would depend on who had provided the information, how trustworthy the source was and how important the story was. Another said, "Major issues which affect the public, who pay for the military - that is need to know.' Another long-term journalist said:

Being one of the old school that always tends to modify the 'right to know' mantra with the 'things that serve a beneficial purpose and I decide what's beneficial' (we all do it in the media so why not admit it), then this question is not too hard.

\section{Attitudes to 'embedding'}

Despite the NZDF preferring the term 'facilitation', journalists felt they had been 'embedded' when they travelled to conflict areas with the military. Generally, they recognised the potential limitations of embedding. However, they felt benefits outweighed the shortcomings.

Only one interviewee expressed worries about embedding. This radio 
journalist thought embedded journalists were controlled: 'I'm personally concerned about embedded journalists, they should be as free as possible to go where they need to go and report what they need to report.' Four other respondents made comments about being embedded with the NZDF. The first, a radio reporter during his visit to East Timor, felt sticking with the Army was good for two reasons: 'The first, I was able to get information and I don't think you spun a line or told anything untrue, secondly I was able to report on what our troops were actually doing.'

Another respondent mentioned that he felt his obligation was to report what the military was doing there 'but we'd do that anyway.' A print journalist, who had been in Bosnia and East Timor said being embedded meant: 'I needed to protect my relationship with the people I depended on for all things.' Another print journalist, said the issues of being embedded 'were irrelevant against the journalist opportunity presented. I would have crawled over broken glass.'

\section{Journalists' attitudes to constraints}

Despite understanding the pros and cons of being with the army, five participants were concerned about constraints they had felt in reporting on defence matters. One spoke about the 'significant barrier' of Army PR: 'The PR person is there to block. You can't explore a subject.' Another, a television reporter, commented about feeling 'stuck in the middle - I need to get my story out and the Army does not want me to send it.' A journalist who had reported defence for the past seven years said:

In a small community you can never afford to blow the bridge behind you. One thing I can't afford to do as the [media organisation] reporter is publish information that will lead to my exclusion from the Defence community - unless it is something I judge to be worth the result.

Respondents also reflected on the control culture of the military. As one put it: 'The whole organisation is gun shy. It is about control. They want to control the release of information in what they see is in their own best interests.' One television journalist was frustrated by restrictions around reporting on the SAS. Another spoke generally about instances where the military blocked access to personnel or refused to front. In one case, when the Singaporean guns blew up in Waiouru: ${ }^{6}$ 
The media was excluded. That was a testy time and if it had been much more serious I can imagine we would have been pushing hard to get pictures, through 'the back door' if necessary. It would have been helpful to have had a good Army contact at that point to explain the Army position to us, rather than just throw down the challenge of no access.

Respondents were asked if they felt obliged to offer 'patriotic' reporting during conflict to shore up public support. A majority of five respondents strongly disagreed. However, one said in practice 'a lot of my reporting was cheerleading. You have to be open to the positive and negative stories. I think journalists tend to go for the negative.' Another respondent, working in television, said: 'Patriotic probably but truthful above polemics.'

Improving the relationship

The NZDF believes that Bosnia provided valuable lessons about dealing with and supporting media (MacKay, 2005). Feedback from the two interviewees who had been to both conflict areas differed. The former print journalist now in public relations agreed:

Bosnia was a steep learning curve for the Army. Bosnia really opened the Army's eyes to the promotional purposes. East Timor was much more about what the Army could do to help — not only the people of East Timor but also the journalists.

However, the other argued that in fact the release of information had become tighter in East Timor than in Bosnia.

\section{Discussion and conclusion}

Compared with the norm of New Zealand journalists (Mackay, 2005, Hollings, Lealand, Samson \& Tilley, 2007) defence reporters we interviewed were highly experienced. There was also a predominance of male reporters (perhaps reflecting the findings of Hollings et al. that longer serving reporters tend to be male). The profile of our interviewees contrasts with overseas findings where journalists covering defence issues were on the whole younger and had less experience.

This study reinforces the view that New Zealand media rely heavily on the Army for conflict coverage. Media need to pursue war news, but, in 
New Zealand at least, their ability to do so is curtailed by organisational budgets. Nearly all media organisations cannot or will not pay for independent travel to conflict zones. Providing coverage of Army deployments in this country is therefore only realistic if the NZDF is able to offer support to the media in the form of transport to and from the AO as well as assistance once there. The support provided, particularly pre-departure and within the AO, was not always consistent.

The practice of embedding is relatively new and the NZ Army does not yet practise the full American model, where each media organisation (for instance a journalist and camera operator) is assigned to a military unit, going with them and sharing the risks and experiences of the ordinary soldier. The New Zealand practice is for all media to arrive in a group and to follow a well organised schedule for the week or so they are in the AO. As one ex Army PRO put it when describing the East Timor experiences:

It was always a nightmare to keep them together-as of course, they always wanted to go off and follow their own angles and try and get different stories that nobody else got! Certainly they only got to see the 'good' stuff on the whole-and they were almost treated like VIPs—not getting dirty, having to do without food or being put in a situation that was unsafe. (Personal interview, 25 February 2008)

This comment demonstrates both the dependence/control dilemma facing journalists and their tacit resistance to it. Further it helps explain why journalists who had gone on NZDF trips did feel 'embedded' (rather than 'facilitated') in terms of their dependence on support. Full embedding is a controversial practice here and overseas, with studies showing the military in favour, and the media split between those who feel it provides too much opportunity for bias and control and those who feel it offers a glimpse into a window they would never otherwise see. Journalists we interviewed were well aware of the pros and cons of embedding.

Our journalists, given their level of experience, were unsurprisingly philosophical about the level of 'spin' they were exposed to, recognising the military's desire for positive stories and manipulation techniques were similar to those of other government departments. However, dependence on the military to get to the AO - perhaps more extreme in New Zealand than other countries - both increases the exposure to 'good news' within tightly 
controlled visit programmes and results in some feeling of obligation to report the positives - even though Kiwi journalists roundly rejected any suggestion they should be patriotic.

The right to know, and who indeed has it, is crucial in the relationship between the military and media. As with findings of studies overseas, particularly from the United states and the Britain (for instance: Boyd-Barrett, 2004; Braestrup, 1985; Katovsky \& Carlson, 2003; Knightley, 2003; and Michandi, 2003) the evidence was that the NZ Army does block the New Zealand media's access to information and journalists are aware and concerned about this. Kiwi reporters' experiences matched those internationally, where traveling in media 'pools', with set programmes, provided an additional constraint to reporting individual story lines and getting a 'scoop' was impossible. Army public relations officers did not recognise the constraints the media faced when visiting the AO in large pools.

The interviews indicate that New Zealand journalists place more trust in the Army on matters of operational security than overseas journalists and their respective militaries. Our interviewees said they would desist from reporting information that would put people's lives at risk. Overseas, particularly in the United States and Britain, but also to some extent Australia, findings are that journalists are more cynical in their approach to operational security, believing that restrictions might only be a way of the military avoiding the release of information that might be embarrassing (see for instance: Hickey, 2004; Katovsky \& Carlson, 2003; Young \& Jesser, 1997).

There was some evidence to support the view that since Bosnia the military has become more professional in meeting the needs of reporters. However, a better media relations and support service, while appreciated by journalists, is a double-edged sword for them. Professional media management also protects the interests of the organisation and the question for journalists is what sort of access are they getting, and what sort of stories are they being guided to or away from? The defence reporter who complained about tighter information control since Bosnia touched on this issue

Sambrook (2003) complains that embedding leads to a snapshot view of warfare's grassroots where the big issues are ignored. Commercial media pressures also lead to an emphasis on human interest. In the New Zealand context, both the military and the media were satisfied with the reporting results of the visits, indicating that to some extent reporters and their 
management were happy with 'softer' background news stories that broadly met the Army's PR objectives.

Neither the New Zealand media nor the NZDF have a full grasp of what embedding in the full USA style would mean. Eventually, the New Zealand media will demand more access to deployed personnel, and the military must find ways to accommodate their requests. Embedding satisfies one aspect of the 'right to know' but journalists we spoke to identified the pressures of dependency and the restrictions of maintaining a working relationship with the army. Maintaining good reporting standards in these circumstances requires talent, experience and media resourcing. For the military, despite the increasing professionalism of its public relations officers and the potentials of embedding journalists, the challenge remains the same. How can it establish procedures that meet media needs while protecting its own legitimate operational security concerns? The media-military interface will remain contested territory and for the sake of democracy this continued contestation is a good thing.

\section{Notes:}

1. Operation Iraqi Freedom began at 5.30am, 20 March 2003 and President G. W. Bush declared it over on 1 May 2003.

2. Jensen (2003) mentions that the rules included reporters not being able to travel independently, interviews all had to be on the record, and officers could censor or temporarily restrict 'operationally sensitive' information. In the first two weeks of the war two reporters, Christian Science Monitor's Philip Smucker and Fox's Geraldo Riveria, were removed from the field for allegedly giving too much information on television.

3. The topic formed the basis of an interview with journalist John Stevenson on Radio New Zealand's Sunday Morning show hosted by Chris Laidlaw (17 October 2004) and an article entitled "Embedded' in Iraq: five views on who controls the news' with a number of contributors in Te Waha Nui (2004).

4. 61 NZDF personnel were deployed as a Light Engineer Group to Southeast Iraq to undertake humanitarian and reconstruction tasks.

5. The Australian Defence Force has an official policy for dealing with the media during war-JSP (AS)41 'Defence Public Information Policy During Periods of Tension and Conflict'. The New Zealand Defence Force does not have a similar policy, and has never had one in the past.

6. In March 1997 two Singaporean soldiers were killed when a round of ammunition exploded prematurely during a training exercise at Waiouru. 


\section{References}

Boyd-Barrett, O. (2004). Understanding the second casualty. In S. Allan \& B. Zelizer (Eds.), Reporting war: Journalism in wartime. London: Routledge.

Braestrup, P. (1985). Battle lines: The report of the Twentieth Century Fund Task Force on the military and the media. New York: Priority Press Publications.

Bridges, R.M. (1995). Have we learned our lesson? Army 45(8), 29-32.

Dow, J. (2004). 'Embedded' in Iraq: 5 views on who controls the news, Te Waha Nui, p. 24.

Float, R. A. (2000). Armed forces and the media - improving the relationship. The British Army Review, 125, 83-95.

Galloucis, M.S. (1996). The Military and the media, Army, 46(8), 14-22.

Gorman, L., \& McLean, D. (2003). Society in the twentieth century-a historical introduction. Oxford: Blackwell Publishing.

Grunig, J. E. (1990). Theory and practice of interactive media relations. Public Relations Quarterly, 35(3), 18-23.

Harrison, J. (2004). Appointed public officials and public relations practice: Accountability ethics and professionalism in the 'children overboard' affair. Asian Pacific Public Relations Journal, 5(1), 1-17.

Hickey, N. (2002). Access denied. Columbia Journalism Review, 40(5), 26-32.

Hiebert, R. E.(1993). Public relations as a weapon of modern warfare. In B.S. Greeenberg \& W. Grantz (Eds.), Desert Storm and the mass media. New Jersey: Hampton Press.

Hollings, J., Lealand, G., Samson, A., \& Tilley, E. (2007). The big NZ journalism survey: Underpaid, under-trained, under-resourced, unsure about the future-but still idealistic. Pacific Journalism Review, 13(2), 175197).

Hooper, A.(1982). The military and the media. England: Gower.

Jacobs, A. (2003, March 2). My week at embed boot camp. New York Times Sunday Magazine, pp.34-36.

Jensen, R. (2003). The military's media. Retrieved on 4 April 2004 from: www.nowarcollective.com

Katovsky, B., \& Carlson, T. (2003). Embedded: The media at war in Iraq. Connecticut: The Lyons Press.

Kennedy, W.V. (1993). The military and the media-Why the press cannot be trusted to cover a war. Connecticut: Greenwood.

Knightley, P. (2000). The first casualty: The war correspondent as hero and myth-maker from the Crimea to Kosovo. London: Prion.

MacKay, D. E. (2005). Media relations in crucial times-the New Zealand Army in Bosnia and East Timor: Can the military and the media co-exist? Unpublished research report, Department of Communication \& Journalism, Massey University.

Mackie, R. B. (1999). Can the military and the media cooperate? Research essay submitted to the New Zealand Defence Force Command and Staff College, Whenuapai, New Zealand. (Available from the Defence Library, Wellington, New Zealand.) 
Marken, G. A. (2001). Journalists vs PR people - we're making the bullets they shoot. Public Relations Quarterly, 46(2), 29-32.

Mercer, D., Mungham, G., \& Williams, K. (1987). The fog of war-the media in the battlefield. London: Heinemann.

Mirchandani, P. (2003). The army and the media. Australian Army Journal, 1(1), 59-70.

Pasquarett, M. (2003). Reporters on the ground: The military and the media's joint experiences during Operation Enduring Freedom. Centre of Strategic Leadership Issue Paper, October. Retrieved on 9 December 2004 from: www.carlisle.army.mil

Rafeeq, A. (2007). Covering conflicts: The coverage of Iraq War II by The New Zealand Herald, The Dominion Post and The Press. Unpublished PhD thesis, University of Canterbury, Christchurch, N.Z.

Sambrook, R. (2003). Military and the media. Royal United Service Institute Journal, August, 40-45.

Seccombe, M. (2003). Propaganda games give a distorted view of reality. Retrieved on 26 March 2004, from: www.smh.com.au

Taylor, K (2004, September 25). PR spending spins out of control. Weekend Herald, p. B5.

Webster, F. (2003). Information warfare in an age of globalization. In D. K. Thussu, $\&$ D. Feedman (Eds.) War and the media. London: Sage.

Williams, K. (1993). The light at the end of the tunnel: The mass media public opinion and the Vietnam War. In J. Eldridge (Ed.), Getting the message: News, truth and power. London: Routledge.

Williams, K. (2003). Understanding media theory. London: Oxford University Press.

Young, P.R. (Ed.). (1992). Defence and the media in the time of limited war. London: Frank Cass \& Co.

Young, P., \& Jesser, P. (1997). The media and the military-from the Crimea to Desert Strike. Australia: Macmillan Education Australia.

Denise Mackay is communications manager for the Red Cross and previously worked in public relations for the NZ Army. Dr Margie Comrie is associate professor in Massey University's Department of Communication, Journalism and Marketing. She has researched and written extensively about the New Zealand news media.

m.a.comrie@massey.ac.nz 